\title{
Solitary benign parietal lesions seen on CT in cancer patients
}

\author{
Aung Zaw Win \\ San Francisco VA Medical Center, United States
}

Correspondence: Aung Zaw Win. Address: Division of Nuclear Medicine, Department of Radiology, San Francisco VA Medical Center, San Francisco, California, United States. E-mail: aungzwin@gmail.com

Accepted: June 5, 2014

Online Published: August 27, 2014

DOI : $10.5430 / j b g c . v 4 n 4 p 1$

URL: http://dx.doi.org/10.5430/jbgc.v4n4p1

\begin{abstract}
Benign skull lesions are routinely encountered in clinical practice. The aim of this review is to describe the Computed tomography (CT) findings of solitary benign parietal lesions. Benign parietal bone lesions can exist in patients with history of cancer. Metastasis to the calvarium is rare compared to other sites in the body and primary skull tumors are even rarer. This is the second report of solitary cholesteatoma occurring in the parietal bone. All the clinical cases in this study were histologically proven. Benign solitary parietal lesions can have non-specific features on CT and in some cases, only biopsy can give a definite diagnosis.
\end{abstract}

\section{Key words}

Parietal bone, Benign, Isolated lesion, CT, Cancer

\section{I ntroduction}

Skull lesions are routinely encountered in clinical practice. Most of the parietal lesions in this study were found incidentally. Benign skull tumors are more common than malignant tumors. The skull bones are affected by diseases similar to those seen in the other bones. Conventional skull radiographs often fail to detect skull lesions ${ }^{[1]}$. It is important to accurately characterize skull lesions so that appropriate treatment decisions can be made. False positive lesions can lead to unnecessary surgical intervention or radiation. Prostate, breast and lung primaries account for the majority of skull metastases ${ }^{[2]}$. In general, secondary metastases tend to show up as multiple lesions and solitary bony lesions are usually benign ${ }^{[3]}$. Tumors usually spread to the skull hematogenously. Skull metastasis can occur in about $15 \%$ of all cancer patients ${ }^{[4]}$. Skull metastases can have lytic, sclerotic or mixed lytic and sclerotic appearances ${ }^{[4]}$. Metastases are usually osteolytic, except when the primary is from the prostate, when it is osteoblastic. In breast cancer, the skull metastases may appear as mixed lucent and sclerotic areas. Many benign bone conditions can mimic neoplasms in the skull.

Secondary tumors of the skull are more common than primary tumors. Primary skull tumors account for $0.8 \%$ of all bone tumors ${ }^{[5]}$. Computed tomography (CT) is rapid and easily performed, also in monitored patients ${ }^{[6]}$. It is the most relevant imaging procedure for surgical lesions ${ }^{[6]}$. The scanning time is longer for MRI and the problem with the monitoring of patients outside the MRI field is present ${ }^{[6]}$. CT is superior to MRI in the assessment of periosteal reaction and pathological fractures ${ }^{[6]}$. CT is ideal for detecting bone lysis and sclerosis, determining the involvement of each of the two skull tables and the diploe, and is helpful in precisely localizing and delineating a lesion pre-surgically ${ }^{[1]}$. On the other hand, CT 
findings can be non-specific and many differential diagnoses have to be ruled out. Biopsy remains the gold standard for definitive diagnosis of skull lesions. The aim of this review is to describe the CT findings of solitary benign parietal lesions. The following is the summary of the benign bone conditions that can exist in the calvarium.

\section{Methods}

A retrospective study was done on all head CT exams done at the institution between January 1989 and January 2014. The inclusion criteria were patients with histories of cancers, who had solitary benign parietal lesions on head CT. In addition, biopsy confirmation was required for all patients included in this study. Twenty patients met all the criteria. Information on age, sex, biopsy report and history of cancer were collected. The characteristics of patients are listed in the table.

Table. Patient characteristics

\begin{tabular}{|c|c|c|c|c|}
\hline Patient & Age & Sex & Biopsy & Medical History \\
\hline 1 (Figure 1) & 45 & male & Cholesteatoma & Renal cell carcinoma \\
\hline 2 (Figure 2) & 55 & male & Coccidioidomycosis & Prostate cancer \\
\hline 3 (Figure 3a) & 54 & male & $\begin{array}{l}\text { Eosinophilic } \\
\text { Granuloma }\end{array}$ & Lung cancer \\
\hline 4 (Figure $3 b$ ) & 32 & male & $\begin{array}{l}\text { Eosinophilic } \\
\text { Granuloma }\end{array}$ & Thyroid cancer \\
\hline 5 (Figure $4 a$ ) & 56 & male & Epidermoid Cyst & Lung cancer \\
\hline 6 (Figure $4 b$ ) & 48 & male & Epidermoid Cyst & $\begin{array}{l}\text { Hepatocellular } \\
\text { carcinoma }\end{array}$ \\
\hline 7 (Figure 5a) & 38 & male & Fibrodysplasia & Lung cancer \\
\hline 8 (Figure $5 b$ ) & 36 & male & Fibrodysplasia & Colon cancer \\
\hline 9 (Figure $5 c)$ & 44 & male & Fibrodysplasia & Renal cell carcinoma \\
\hline 10 (Figure $5 d$ ) & 37 & male & Fibrodysplasia & Colon cancer \\
\hline 11 (Figure 6a) & 61 & female & Giant Cell Tumor & Breast cancer \\
\hline 12 (Figure 6b) & 57 & female & Giant Cell Tumor & Ovarian cancer \\
\hline 13 (Figure 7a) & 52 & male & Hemangioma & Lung cancer \\
\hline 14 (Figure 7b) & 55 & female & Hemangioma & Breast cancer \\
\hline 15 (Figure 7c) & 60 & male & Hemangioma & Renal cell carcinoma \\
\hline 16 (Figure $7 d$ ) & 68 & male & Hemangioma & Colon cancer \\
\hline 17 (Figure 7e) & 70 & male & Hemangioma & $\begin{array}{l}\text { Hepatocellular } \\
\text { carcinoma }\end{array}$ \\
\hline 18 (Figure 8a) & 65 & male & Osteoma & Prostate cancer \\
\hline 19 (Figure 8b) & 69 & male & Osteoma & Prostate cancer \\
\hline 20 (Figure 9) & 74 & male & Benign (Trauma) & Prostate cancer \\
\hline
\end{tabular}

\subsection{Cholesteatoma}

Cholesteatoma is a cystic lesion covered by stratified squamous cell epithelium over a fibrous stroma of variable thickness ${ }^{[7]}$. This is the second report of solitary cholesteatoma occurring in the parietal bone ${ }^{[8]}$. Complete resection is usually curative $^{[8]}$. It has a lytic appearance on CT and only the inner table can be involved (see Figure 1).

\subsection{Coccidioidomycosis}

Patients acquire coccidioidomycosis by inhalation of the spores and infections can be serious in patients with an immunocompromised state such as our patient (see Figure 2). Disseminated disease can involve meninges, bone, joints, 
skin, or soft tissues. Treatment can involve surgical debridement of the skull lesion. The disease can also manifest as osteomyelitis of the skull ${ }^{[9]}$. On CT scan, there can be focal erosion of the skull ${ }^{[10]}$.

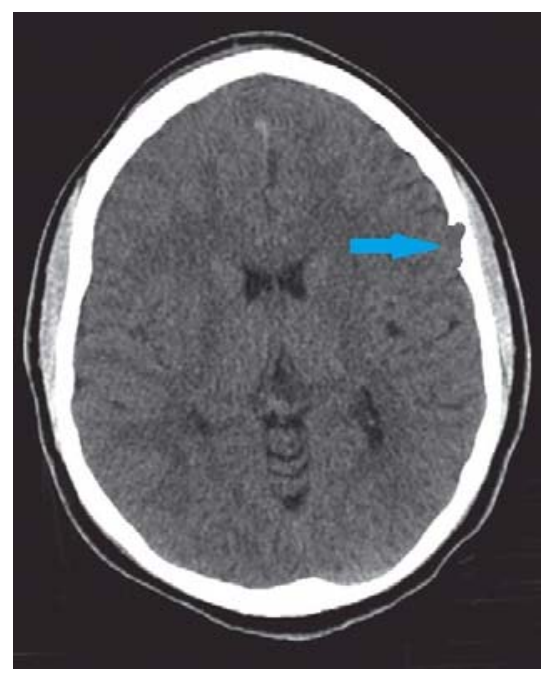

Figure 1. Axial CT of the head showing cholesteatoma in the left parietal bone, involving only the inner table of the skull.

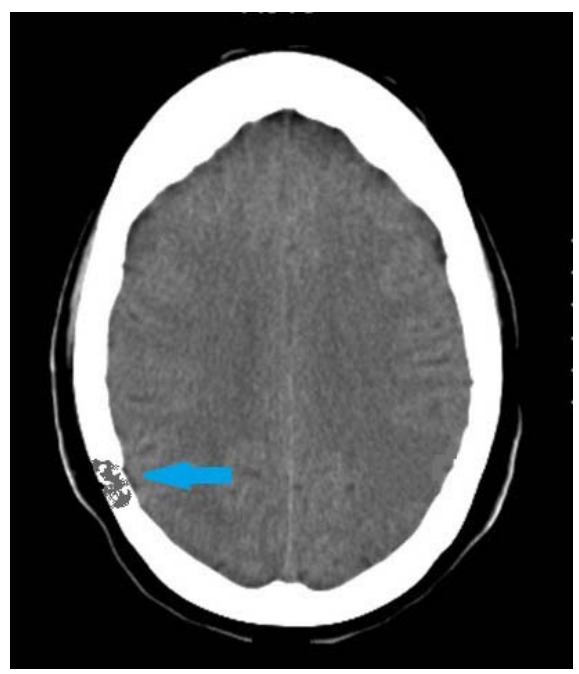

Figure 2. CT image showing an osteolytic lesion in the right parietal bone, confirmed to be coccidioidomycosis.

\subsection{Eosinophilic granuloma}

Eosinophilic granuloma is the most common type of Langerhans cell histiocytosis ${ }^{[1]}$. Disease severity is inversely related to the age of onset and spontaneous resolution is common ${ }^{[1]}$. It originates in the diploic space. It presents as a welldemarcated lytic mass, often containing a central "button sequestrum" of residual bone ${ }^{[2]}$. There may be a "beveled edge" due to greater lysis of the inner table more than the outer table ${ }^{[2]}$ (see Figure 3).

Figure 3. (a) Eosinophilic granuloma with possible "button sequestrum". (b) CT in bone window showing an osteolytic mass in the left parietal bone.

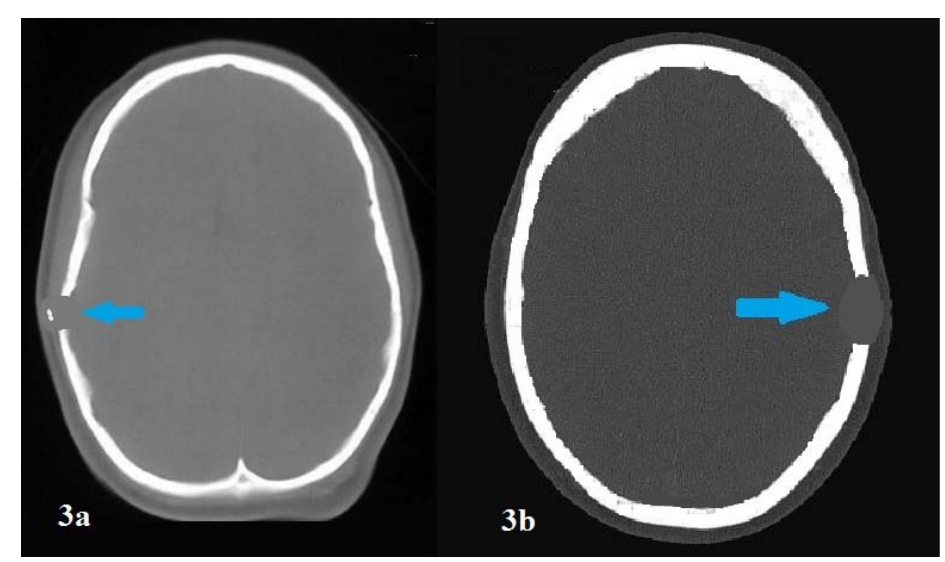

\subsection{Epidermoid cyst}

Epidermoid cysts are derived from ectodermal cells which remain within the cranial bones during embryonic development ${ }^{[11]}$. They can be congenital or acquired through trauma ${ }^{[12]}$. They are slow growing and the parietal bone is the most common location for epidermoid cysts ${ }^{[11]}$. They can remain asymptomatic for many years ${ }^{[12]}$. They can recur after the surgical removal ${ }^{[11]}$. On CT, they appear as homogeneous lytic lesions which can involve both tables of the cranial bone, with or without a sclerotic rim ${ }^{[11]}$. Calcification is present in $10 \%-25 \%$ of the lesions ${ }^{[12]}$ (see Figure 4). 
Figure 4. (a) CT image showing an epidermoid cyst with a sclerotic rim, affecting both tables of the cranial bone. (b) Axial CT showing a parietal epidermoid cyst with internal calcification.

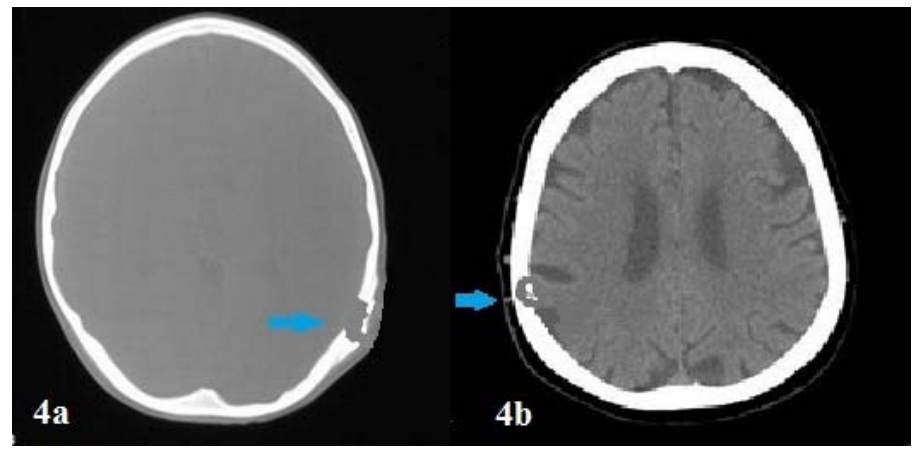

\subsection{Fibrodysplasia}

In fibrodysplasia, osteoblast dysfunction causes replacement of normal bone with woven bone, which has mixed fibrous and osseous components ${ }^{[13]}$. Although it can be caused by a gene mutation, it is not inherited or passed on to the children of affected patients ${ }^{[14]}$. Fibrodysplasia usually affects the frontal and temporal bones ${ }^{[1]}$. The calvarium is involved in both monostotic and polyostotic forms ${ }^{[2]}$. There is no periostitis and lesions commonly have a ground glass appearance on CT ${ }^{[13]}$. However, other patterns such as amorphous and attenuated, homogeneously cystic or sclerotic can exist ${ }^{[12]}$. In addition, these lesions may also have an abnormal trabeculae pattern similar to that of a fingerprint ${ }^{[12]}$. Fibrodysplasia can present as both lytic and sclerotic lesions ${ }^{[12]}$. Garfinkle et al. reported that CT is the most useful diagnostic tool for detecting fibrodysplasia ${ }^{[1]}$ (see Figure 5).

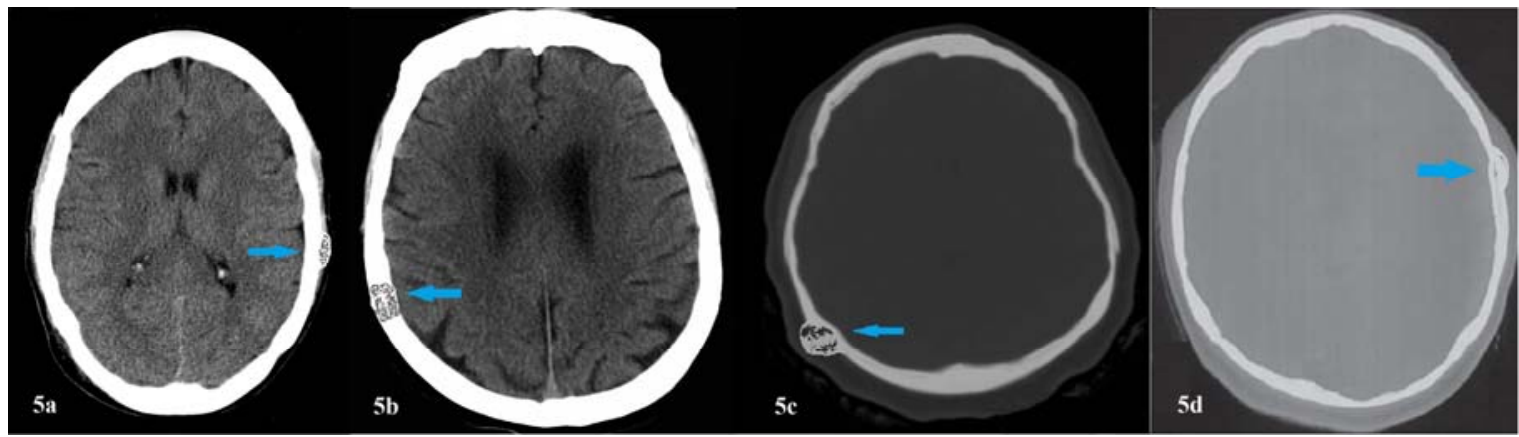

Figure 5. (a, b, c, d) CT images showing "ground glass" appearance of fibrodysplasia.

\subsection{Giant cell tumor}

Giant cell tumors reported in the skull are rare ${ }^{[15]}$. Giant cell tumors are derived from the monocytic cells of the hematopoetic system ${ }^{[15]}$. There is a female predominance and patients usually present with pain ${ }^{[15]}$. They are usually found in the sphenoid bone ${ }^{[16]}$. Surgical excision is the treatment of choice ${ }^{[15]}$. On CT, they appear as lytic lesions with a nonsclerotic border ${ }^{[15]}$ (see Figure 6).

Figure 6. $(\mathrm{a}, \mathrm{b})$ On CT, giant cell tumor can be seen as an intradiploic osteolytic mass.

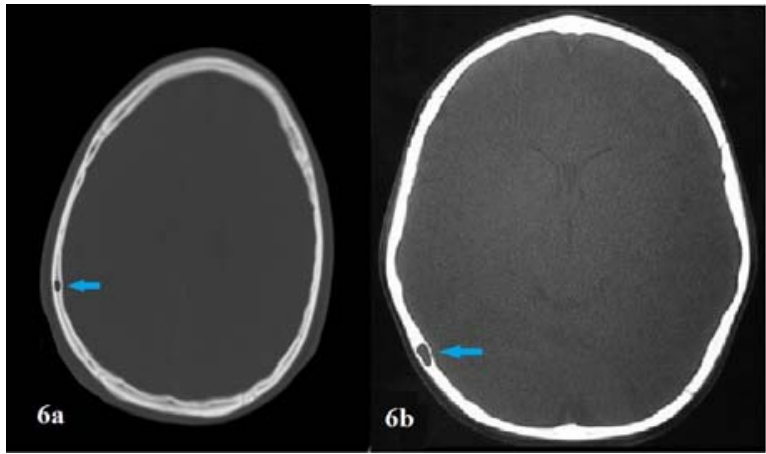

ISSN 1925-4008 E-ISSN 1925-4016 


\subsection{Hemangioma}

Hemangiomas are vascular lesions arising from the diploic space in the skull. They are three times more common in females than males ${ }^{[17]}$. Hemangiomas are slow growing, painless and malignant transformation is unknown ${ }^{[17]}$. The parietal bone is most commonly affected followed by the frontal bone ${ }^{[12]}$. There are two types of hemangiomas: traumatic and congenital ${ }^{[12]}$. Mostly, skull hemangiomas are asymptomatic, require no treatment, and have no significant sequelae ${ }^{[17]}$. On CT, they can assume the heterogeneous sunburst or honeycomb pattern ${ }^{[18]}$. They appear as lytic lesions with or without sclerotic margins. Both the outer and inner table of the calvarial bone can be eroded as the lesion expands ${ }^{[1]}$ (see Figure 7).

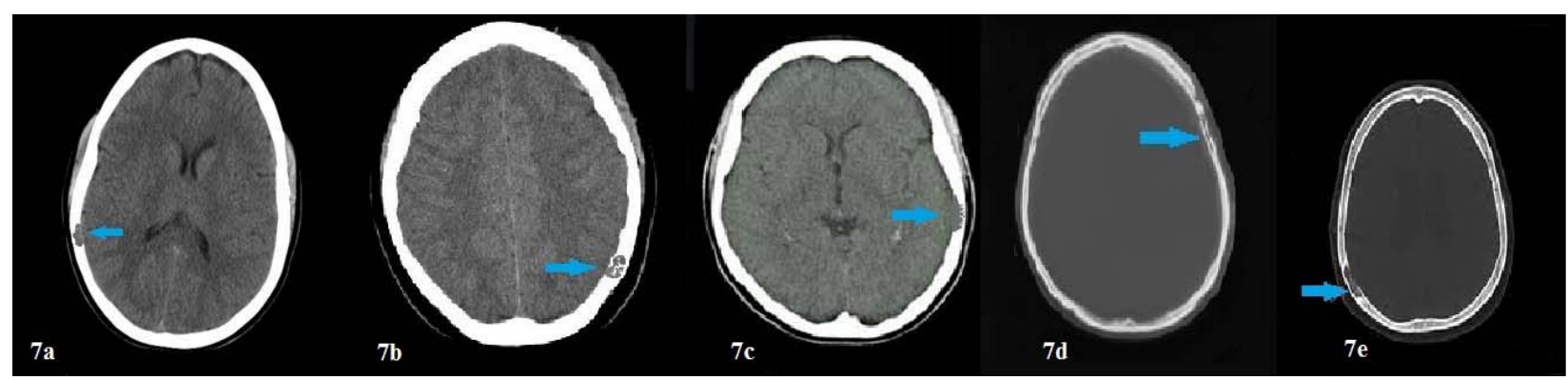

Figure 7. (a, b, c, d, e) CT images of hemangiomas showing involvement of the diploic space.

\subsection{Osteoma}

An osteoma is a benign, slow-growing bony outgrowth of membranous bones and frequently involves the calvaria ${ }^{[12]}$. The frontal bone and mastoid air cells are common sites ${ }^{[12]}$. The highest incidence is in the sixth decade of life ${ }^{[12]}$. Osteomas are surgically curable ${ }^{[12]}$. Round sclerotic lesions arising from the outer table without involvement of the diploe are typically seen on CT. It can also originate from the inner table ${ }^{[1]}$ (see Figure 8).

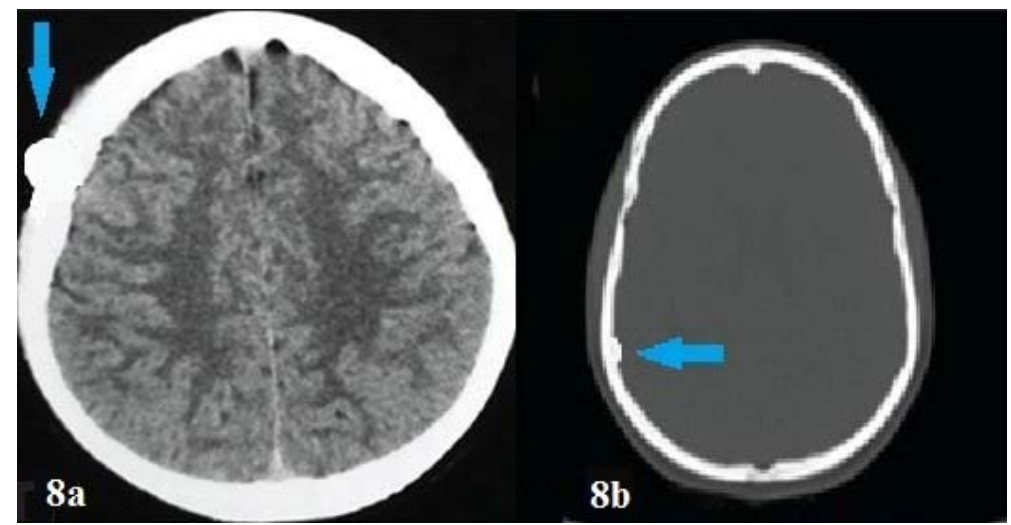

Figure 8. Axial CT image shows a round sclerotic lesion originating from the outer table (a), from the inner table (b).

\subsection{Trauma}

The traumatic parietal lesion in this study was due to falls (see Figure 9). The traumatic parietal lesion appeared as a focal lytic lesion in this study. Osteolytic skull lesions can result from trauma ${ }^{[19]}$. Blunt traumas can sometimes break the inner table without breaking the outer table ${ }^{[20]}$. Chronic injuries can show skull abnormalities without any signs of parenchymal brain injury and patients may be asymptomatic ${ }^{[20]}$. Minor or moderate head trauma can cause an intradiploic cyst especially in the parietal zone in adults many years after head trauma ${ }^{[19]}$. Those cysts are benign and exploratory surgery should be avoided unless they are symptomatic ${ }^{[19]}$. CT gives more information than MRI on bony changes in skull injuries ${ }^{[21]}$. 
Figure 9. CT image showing a lytic right parietal lesion which extended to the inner table of the calvarium. Biopsy confirmed it as a benign lesion. This patient had a history of multiple falls.

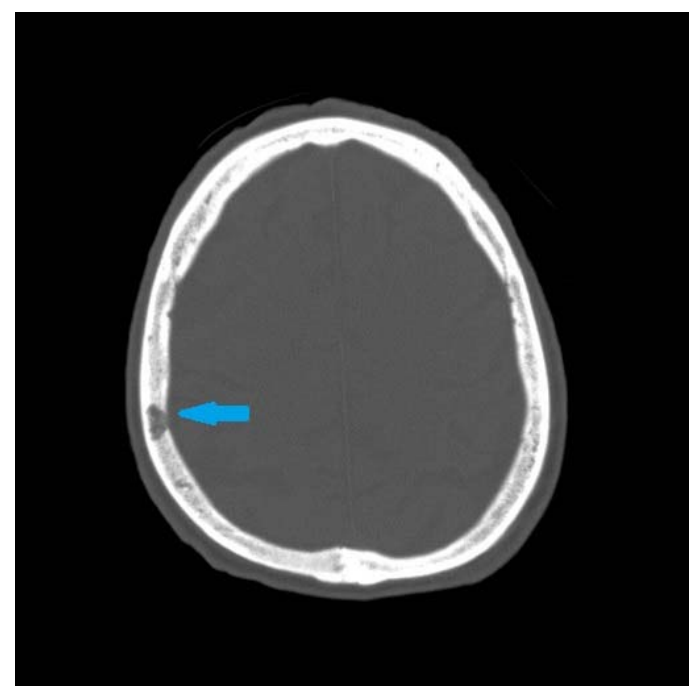

\section{Conclusion}

In some cases, suspicious lesions can be monitored with serial CT exams. Careful observation may be appropriate when neural structures are not at risk, and when the patient is a poor surgical candidate. This study showed that benign parietal lesions can exist in patients with histories of cancer. Benign solitary parietal lesions can have non-specific features on CT and benign and malignant lesions cannot be distinguished based on CT alone. CT features can overlap between benign and malignant bone conditions. Therefore, in cases where malignancy is highly suspected, biopsy should be done. Histopathological verification may help avoid unnecessary cancer treatment.

\section{References}

[1] Garfinkle J, Melançon D, Cortes M, Tampieri D. Imaging pattern of calvarial lesions in adults. Skeletal Radiol. 2011 Oct; 40(10): 1261-73. PMid: 20526773. http://dx.doi.org/10.1007/s00256-010-0971-8

[2] Carter R, Anslow P. Imaging of the calvarium. Semin Ultrasound CT MR. 2009 Dec; 30(6): 465-91. PMid: 20099635. http://dx.doi.org/10.1053/j.sult.2009.08.004

[3] Rosenthal DI. Radiologic diagnosis of bone metastases. Cancer. 1997 Oct 15; 80(8 Suppl): 1595-607. http://dx.doi.org/10.1002/(SICI)1097-0142(19971015)80:8+<1595::AID-CNCR10>3.0.CO;2-V

[4] Mitsuya K, Nakasu Y, Horiguchi S, et al. Metastatic skull tumors: MRI features and a new conventional classification. J. Neurooncol. 2011; 104 (1): 239-45. PMid: 21110218. http://dx.doi.org/10.1007/s11060-010-0465-5

[5] Bourekas EC, Cohen ML, Kamen CS, Tarr RW, Lanzieri CF, Lewin JS. Malignant hemangioendothelioma (angiosarcoma) of the skull: plain film, CT, and MR appearance. AJNR Am J Neuroradiol. 1996 Nov-Dec; 17(10): 1946-8. PMid: 8933884.

[6] Besenski N. Traumatic injuries: imaging of head injuries. Eur Radiol. 2002 Jun; 12(6): 1237-52. PMid: 12042929. http://dx.doi.org/10.1007/s00330-002-1355-9

[7] Migirov L, Greenberg G, Eyal A, Wolf M. Imaging prior to endoscopic ear surgery: clinical note. Isr Med Assoc J. 2014 Mar; 16(3): 191-3. PMid: 24761713.

[8] Bahl A, Lawson A, Cohen M, Sinha S. Solitary cholesteatoma of the parietal bone. Pediatr Neurosurg. 2012; 48(2): 129-30. PMid: 23037636. http://dx.doi.org/10.1159/000342683

[9] Gillespie R. Treatment of cranial osteomyelitis from disseminated coccidioidomycosis. West J Med. 1986 Nov; 145(5): 694-7. PMid: 3798920.

[10] Baddley JW, Cobbs CS, Pappas PG. Surgical treatment of multiple skull abscesses associated with coccidioidomycosis. Mycoses. 2004 Feb; 47(1-2): 69-71. PMid: 14998403. http://dx.doi.org/10.1046/j.0933-7407.2003.00938.x

[11] Arana E, Latorre FF, Revert A, Menor F, Riesgo P, Liaño F, et al. Intradiploic epidermoid cysts. Neuroradiology. 1996 May; 38(4): 306-11. PMid: 8738084. http://dx.doi.org/10.1007/BF00596575 
[12] Lerner, A., Lu, D.A., Allison, S.K., Shiroishi, M.S., Law, M., White, E.A. Calvarial Lesions and Pseudolesions: Differential Diagnosis and Pictorial Review of Pathologic Entities Presenting with Focal Calvarial Abnormalities. Neurographics. 2013; 3(3): 108-117. http://dx.doi.org/10.3174/ng.3130058

[13] Kransdorf MJ, Moser RP Jr, Gilkey FW. Fibrous dysplasia. Radiographics. 1990 May; 10(3): 519-37. PMid: 2188311. http://dx.doi.org/10.1148/radiographics.10.3.2188311

[14] DiCaprio M. R., Enneking W. F. Fibrous Dysplasia. Pathophysiology, Evaluation, and Treatment. J Bone Joint Surg Am. 2005; 87: 1848-1864. PMid: 16085630. http://dx.doi.org/10.2106/JBJS.D.02942

[15] Patankar T, Varma R, Krishnan A, Prasad S, Desai K, Castillo M. Radiographic findings in tuberculosis of the calvarium. Neuroradiology. 2000 Jul; 42(7): 518-21. PMid: 10952185. http://dx.doi.org/10.1007/s002340000317

[16] Tsai MS, Tarn JJ, Liu KS, Chou YL, Shen CL. Multiple actinomyces brain abscesses: case report. J Clin Neurosci. 2001 Mar; 8(2): 183-6. PMid: 11243774. http://dx.doi.org/10.1054/jocn.1999.0744

[17] Malde R, Moss T, Malcolm G, Whittlestone T, Bahl A. Multiple intraosseous calvarial hemangiomas mimicking metastasis from renal cell carcinoma. Adv Urol. 2008; 176392. PMid: 18604286.

[18] Atcı IB, Albayrak S, Yılmaz N, Uçler N, Durdağ E, Ayden O, et al. Cavernous hemangioma of the parietal bone. Am J Case Rep. 2013 Jul 10; 14: 401-4. PMid: 24133611. http://dx.doi.org/10.12659/AJCR.889388

[19] Menkü A, Koç RK, Tucer B, Akdemir H. Is skull fracture necessary for developing an intradiploic pseudomeningocele as a complication of head injury in adulthood? Acta Neurochir (Wien). 2004 Jun; 146(6): 623-7. PMid: 15168231. http://dx.doi.org/10.1007/s00701-004-0263-y

[20] Seo BR, Lee JK, Jeong IH, Moon SJ, Joo SP, Kim TS, et al. Post-traumatic intradiploic leptomeningeal cyst of the posterior fossa in an adult. J Clin Neurosci. 2009 Oct; 16(10): 1367-9. PMid: 19556133. http://dx.doi.org/10.1016/j.jocn.2008.10.018

[21] Açikgöz B, Tekkök IH. Post-traumatic intradiploic leptomeningeal fistula and cyst. J Clin Neurosci. 2002 Jul; 9(4): 468-73. PMid: 12217685. http://dx.doi.org/10.1054/jocn.2002.1066 